\title{
PERAN HUMAS PT. INDAH KIAT PULP \& PAPER DALAM UPAYA MENUMBUHKAN CITRA POSITIF MASYARAKAT DESA TUALANG KABUPATEN SIAK
}

\author{
${ }^{1}$ Meida Diwan; ${ }^{2}$ Abdul Aziz; ${ }^{3}$ Dyah Pithaloka \\ Fakultas Ilmu Komunikasi Universitas Islam Riau \\ Email: 1meidadiwan1111@ gmail.com; 2abdulaziz@comm.uir.ac.id; \\ 3pithaloka@comm.uir.ac.id
}

\begin{abstract}
Abstrak
Penelitian tentang Peran Humas PT. Indah Kiat Pulp \& Paper Dalam Upaya Menumbuhkan Citra Positif Masyarakat Desa Tualang Kabupaten Siak. Permasalahan yang diangkat dalam penelitian ini adalah bagaimana Peran Humas PT. Indah Kiat Pulp \& Paper Dalam Upaya Menumbuhkan Citra Positif Masyarakat Desa Tualang Kabupaten Siak. Analisis Penelitian ini menggunakan metode deskriptif kualitattif. Teknik pengumpulan data menggunakan wawancara, observasi dan dokumentasi. Dari data yang diperoleh menunjukkan bahwa peran Humas PT. Indah Kiat Pulp \& Paper Dalam Upaya Menumbuhkan Citra Positif Masyarakat Desa Tualang Kabupaten Siak cukup baik, diharapkan pada humas PT. Indah Kiat Pulp \& Paper lebih aktif lagi dalam mengontrol pelaksanaan dari program yang dijalankan hingga selesai, agar program yang dijalankan mencapai target dan sasaran yang sesuai dengan ketentuan yang telah ditetapkan.
\end{abstract}

Kata Kunci: Public relations, program public relations

\begin{abstract}
This research is about the role of public relations of PT. Indah Kiat Pulp \& Paper in order to grow positive image of Tualang village society of Siak district. In an organization or in a geverment agency, it is required public relations as part of sosialization and publication related with all information and policies or even important programs of the company.This research used descriptive qualitative method to analyze the data. Data collection technique used were interview, observation, and documentation. Of the data obtained, it showed that the role of public relation of PT. Indah Kiat Pulp \& Paper to grow the positive image of Tualang village society of Siak district has been considered good, it is hoped that public relation of PT. Indah Kiat Pulp \& Paper will be more active in controlling the implementation of the program being run to completion, so that programs can achieve the targets and goals in accordance with the provisions that have been set.
\end{abstract}

Keywords : Public relations, public relations program

\section{PENDAHULUAN}

Pada kegiatan humas terdapat adanya suatu kegiatan timbal balik antara lembaga dengan publiknya, sehingga terjadilah suatu pengertian bersama dalam 
meraih kepentingan bersama. Dalam proses komunikasinya, humas tidak hanya menyampaikan informasi, tetapi juga menerima informasi dari publiknya. Humas adalah suatu kegiatan komunikasi dan penafsiran, serta komunikasi dan gagasangagasan dari suatu lembaga kepada publiknya dan pengomunikasian informasi serta pendapat dari publiknya itu kepada lembaga tadi, dalam usaha yang jujur untuk menumbuhkan kepentingan bersama sehingga dapat tercipta persesuaian yang harmonis dari lembaga itu dengan masyarakatnya (Suhendang, 2004: 45).

Setiap perusahaan mempunyai citra sebanyak jumlah orang yang memandangnya. Sehingga berbagai citra perusahaan datang dari pelanggan perusahaan, pelanggan potensial, bankir, staf perusahaan, pesaing, distributor, investor, asosiasi dagang, dan gerakan pelanggan di sektor perdagangan yang mempunyai pandangan terhadap perusahaan (Soemirat, 2002: 113). Setiap perusahaan baik swasta maupun pemerintah, apalagi perusahaan yang berskala besar sangat memerlukan seorang public relation untuk meningkatkan dan memajukan perusahaan. Public relation dalam menjalankan fungsi dan tugas penerangannya sebagai wahana komunikasi kedalam berusaha menyelenggarakan ke dalam tubuh organisasi, sedangkan komunikasi keluar memberikan informasi kepada masyarakat dan lingkungan yang sehat kepada masyarakat sehingga mereka mendukung dan mengetahui yang diharapkan.

Dalam upaya menumbuhkan citra positif masyarakat, PT.Indah Kiat Pulp \&Paper membentuk humas agar dapat menampung dan menjawab segala keluhan, tuntutan dan kebutuhan yang diajukan oleh masyarakat dilingkungan perusahaan, mengingat perusahaan ini berdiri dan tumbuh kembang dilingkungan sekitarnya yang secara tidak langsung mempengaruhi jalannya perusahaan tersebut.Melalui program atau kegiatan-kegiatan kerja humas, humas PT.Indah Kiat Pulp \&Paper mensosialisasikan program-program kerja humas kepada masyarakat agar menimbulkan citra positif terhadap perusahaan dari masyarakat wilayah operasional.

Program tersebut bertujuan dalam pengembangan ekonomi yang berkelanjutan dengan memperhatikan tanggung jawab sosial perusahaan dan menitikberatkan pada keseimbangan antara perhatian terhadap aspek ekonomis, sosial, dan lingkungan.seperti:

1. Kesehatan masyarakat.

2. Pengembangan pendidikan, diutamakan pada peningkatan mutu pendidikan dapat dilakukan dengan mengadakan perpustakaan oleh perusahaan.

3. Pengembangan ekonomi, terdiri dari program pertanian dan usaha lokal. Pengembangan usaha lokal adalah motor usaha pertumbuhan ekonomi berkelanjutan.

4. Pembangunan, Peningkatan prasarana seperti perbaikan jalan dan saluran air, pembangunangedung sekolah, pengadaan air bersih,irigasi, dan pembangunan tempat penimbunan sampah (Arsip Humas).

Program pengembangan ini bertujuan sebagai bukti bagaimana PT. Indah Kiat Pulp \& Paper benar-benar memperhatikan secara serius terhadap seluruh aspek yang ada disekitar perusahaan, serta agar dapat membangun dan menumbuhkan citra positifmasyarakat, untuk mendukung hal tersebut diperlukan adanya partisipasi dari seluruh elemen masyarakat. Oleh karena itu partisipasi masyarakat dalam proses pengembangan mutlak diperlukan. Salah satu akibat jika masyarakat 
tidak ikut berpartisipasi adalah masyarakat merasa acuh tak acuh terhadap program pengembangan yang ada.

Berdasarkan pra survei dilapangan penulis menemukan adanya keluhan dari warga sekitar terhadap program yang dilaksanakan oleh humas yaitu dari program pengembangan ekonomi dan program pembangunan. Dari program pengembangan ekonomi, berkurangnya bantuan berupa peminjaman modal dan pemberian bibit dari sektor pertanian maupun perikanan pada kelompok masyarakat kurang mampu yang sangat berdampak pada perekonomian masyarakat yang tidak memiliki pekerjaan tetap, serta sulitnya mendapatkan lowongan pekerjaan dari perusahaan yang dirasakan oleh warga sekitar. Dengan mulai menurunnya sikap masyarakat maka otomatis akan berdampak pula pada citra perusahaan yang akan dirasakan, oleh karna itu seorang humas dituntut bagaimana caranya agar bisa kembali menumbuhkan citra positif dari masyarakat. Berdasarkan fenomenafenomena diatas, maka penulis tertarik untuk melakukan penelitian dengan judul "Peran humas PT. Indah Kiat Pulp \& Paper dalam Upaya Menumbuhkan Citra Positif Masyarakat Desa Tualang Kabupaten Siak".

\section{KERANGKA TEORI}

\section{Pengertian Komunikasi}

Komunikasi merupakan suatu proses atau kegiatan yang diantaranya terdapat dua orang atau lebih dalam melakukan pertukaran informasi dengan satu sama lain, yang pada akhirnya akan terjadi saling pengertian yang mendalam. Sebagai makhluk sosial kita tentunya tidak bisa atau tidak terlepas dari suatu kegiatan komunikasi.Dari komunikasi tersebut kita dengan mudahnya bisa memperoleh informasi tentang segala hal yang ingin kita ketahui maupun yang belum sama sekali kita ketahui. Istilah komunikasi atau dalam bahasa inggris communication berasal dari kata latin communication, dan bersumber dari kata communis yang berarti sama. Sama disini maksudnya adalah sama makna. Dalam komunikasi yang melibatkan dua orang, komunikasi berlangsung apabila adanya kesamaan makna (Effendy, 2004:9).

Komunikasi adalah proses penyampaian gagasan, harapan, pesan yang disampaikan melalui lambang tertentu yang mengandung arti, dilakukan oleh penyampaian pesan ditujukan pada penerimaan pesan dengan maksud mencapai kebersamaan untuk menjalin rasa kemanusiaan yang akrab diperlukan saling pengertian sesama anggota masyarakat (Widjaja, 2010: 1).

Komunikasi merupakan aktifitas dasar manusia, dengan berkomunikasi manusia dapat saling berhubungan satu sama lain baik dalam kehidupan sehari-hari seperti dirumah tangga, tempat kerja, pasar, dalam lingkungan masyarakat atau dimana saja, tidak ada manusia yang tidak terlibat dalam komunikasi. Pentingnya komunikasi bagi manusia tidak dapat dipungkiri begitu juga halnya bagi suatu organisasi. Dengan adanya komunikasi yang baik suatu organisasi dapat berjalan lancar dan berhasil dan begitu pula sebaliknya, kurangnya atau tidak adanya komunikasi organisasi dapat macet atau berantakan (Muhammad, 2011: 1).

Dalam hidup bermasyarakat, orang yang tidak pernah berkomunikasi dengan orang lain niscaya akan terisolasi dari masyarakatnya dan pengaruh keterisolasian ini akan menimbulkan depresi mental yang pada akhirnya membawa orang 
kehilangan keseimbangan jiwa. Komunikasi dan masyarakat adalah kata kembar yang tidak dapat dipisahkan satu sama lainnya, sebab tanpa komunikasi tidak mungkin masyarakat terbentuk, sebaliknya tanpa masyarakat maka manusia tidak mungkin dapat mengembangkan komunikasi (Cangara, 2005: 1).

Schramm dan Robert (dalam Tinambunan, 2002: 3) mengemukakan lima pengertian komunikasi yaitu:

1. Komunikasi adalah proses pemberian, penyampaian, pertukaran gagasan, pengetahuan dan lain-lain yang dapat dilalui melalui percakapan, tulisan atau tanda-tanda.

2. Komunikasi adalah proses pengalihan pikiran dan pesan-pesan seperti sarana transportasi mengangkut barang dan manusia. Bentuk dasar komunikasi ditentukan oleh tanda yang bisa dilihat dan suara yang bisa didengar.

3. Dalam banyak hal komunikasi dapat diartikan sebagai suatu sistem yang didalamnya terkandung sumber, pengaruh, terhadap orang lain, tujuan atau sasaran yang melaksanakan rangkaian kegiatan dengan memanipulasi pilihan tanda tertentu yang dapat dialihkan melalui saluran tertentu

4. Kata komunikasi dapat digunakan dalam arti yang luas meliputi prosedur yang mengatur bagaimana pikiran mempengaruhi orang lain.

5. Komunikasi adalah mekanisme hubungan antara manusia yang menyebabkan manusia itu bertahan dan berkembang melalui penyampaian simbol pikiran melalui suatu ruang dan waktu tertentu.

Dari kelima defenisi diatas terkandung beberapa pokok pikiran. pengertian pertama dan kedua didasarkan pada gagasan pengalihan informasi yang dibedakan dalam pengalihan gagasan, pengetahuan, pikiran, pesan-pesan maupun material. Pengertian ketiga dan keempat menekankan pada gagasan pengaruh dan efek tertentu akibat pengalihan itu. Sedangkan pengertian kelima menekankan pada hubungan antar manusia.

Menurut Hovland (dalam Effendy, 2005: 10) komunikasi adalah upaya yang sistematis untuk merumuskan secara tegas azas-azas penyampaian informasi serta pembentukan pendapat dan sikap. Kincaid (dalam Cangara, 2000: 19) menyatakan bahwa komunikasi adalah suatu proses dimana dua orang atau lebih membentuk dan melakukan pertukaran informasi dengan satu sama lain yang pada gilirannya akan tiba pada saling pengertian yang mendalam.

Apabila komunikasi dipandang dari arti yang lebih luas, tidak hanya diartikan sebagai pertukaran berita dan pesan tetapi sebagai kegiatan individu dan kelompok mengenai tukar menukar data, fakta dan ide maka fungsinya dalam sistem sosial.

Untuk memahami fungsi komunikasi, terlebih dahulu harus paham tipe komunikasi. Adapun macam-macam tipe komunikasi adalah:

1. Komunikasi diri sendiri.

2. Komunikasi antar pribadi.

3. Komunikasi publik.

4. Komunikasi massa (dalam Cangara, 2003: 29)

Dari keseluruhan fungsi komunikasi yang diuraikan diatas dapat diambil kesimpulan bahwa komunikasi berfungsi untuk menginformasikan, mendidik, menghibur dan mempengaruhi. Fleur yang dikutip Susanto Sastro Poetra dalam bukunya partisipasi, komunikasi dan disiplin pembangunan nasional (1998) 
menyatakan bahwa seni komunikasi merupakan sarana untuk menyatakan norma kelompok, dan hal itupun merupakan medium untuk pelaksanaan pengawasan sosial, dan peran-peran dibagikan pengkoordinasikan efek dicapai, berbagai harapan telah dapat pula dibuktikan dan keseluruhan proses sosialpun dilaksanakan (Tinambunan, 2002: 8)

\section{Humas(Public Rlation).}

Humas merupakan sesuatu yang merangkum keseluruhan komunikasi yang terencana baik itu kedalam maupun keluar antara suatu organisasi dengan semua khalayaknya dalam rangka mencapai tujuan-tujuan spesifik yang berlandaskan saling pengertian (Morrison, 2008: 8).

Menurut Scott M. Cutlip, Allen H. Center, Glen M. Broom (dalam Nova, 2011: 45) Public Relation merupakan fungsi manajemen yang membentuk dan memelihara hubungan yang baik dan saling menguntungkan antara organisasi dan masyarakat, yang menjadi sandaran keberhasilan atau kegagalannya.

Untuk menciptakan suatu hubungan yang baik antara instansi atau lembaga dengan pihak-pihak lain perlu adanya suatu pengertian antara satu dengan lainnya, dan pada akhirnya akan menciptakan kepercayaan dari masyarakat, pemerintah, dan pihak-pihak lain terhadap instansi atau lembaga yang melakukan hubungan masyarakat tersebut. Public relationadalah suatu fungsi manajemen yang menilai sikap publik dan dan melaksanakan rencana kerja untuk memperoleh pengertian dan pengakuan publik (Abdurahman, 2001: 26)

Humas adalah fungsi manajemen yang mengevaluasi sikap publik, mengidentifikasi kebijaksanaan-kebijaksanaan dan prosedur-prosedur seorang individu atau sebuah organisasi berdasarkan kepentingan publik dan menjalankan suatu program untuk mendapatkan pengertian dan penerimaan publik. Humas adalah suatu filasafat sosial dan manajemen yang dinyatakan dalam kebijaksanaan beserta pelaksanaannya, yang melalui interpretasi yang peka mengenai peristiwaperistiwa berdasarkan pada komunikasi dua arah dengan publiknya, berusaha untuk memperoleh saling pengertian dan itikad baik (Moore, 2005: 6).

Humas adalah fungsi manajemen yang unik yang membantu membangun dan memelihara jalur komunikasi, memunculkan pemahaman, kerja sama antara organisasi dan publiknya, melibatkan manajemen permasalahan dan isu, membantu manajemen untuk terus menginformasikan dan tanggap terhadap opini publik, mendefinisikan dan menekankan tanggung jawab manajemen untuk melayani kepentingan umum, membantu manajemen untuk tetap mengikuti dan memanfaatkan perubahan secara efektif, melayani sebagai sistem peringatan dini untuk membantu mencegah kecenderungan negatif dan menggunakan penelitian yang sehat dan etika komunikasi sebagai alat utamanya (Butterick, 2012: 7).

Fungsi public relation dalam menyelenggarakan komunikasi timbal balik dua arah (reciprocaltwo way traffic communication) antara organisasi/badan instansi yang diwakilinya dengan peblik sebagai sasaran (target audience).Pada akhirnya dapat menentukan sukses atau tidaknya tujuan dan citra yang hendak dicapai oleh organisasi bersangkutan. Hal tersebut sesuai dengan intisari definisi kerja Humas oleh Dr. Rex Harlow, dari San Francisco, Amerika tersebut yang menjadi acuan para anggota IPRA (International Public Relations Association) (1978), yang berbunyi: 
"Hubungan masyarakat merupakan komunikasi dua arah antara organisasi dengan publik secara timbal balik dengan meningkatkan pembinaan kerja sama serta pemenuhan kepentingan bersama (Ruslan, 2007: 19).

Menurut para pakar, hingga saat ini belum terdapat konsesus mutlak tentang definisi Public Relation atau Humas. Sebagai acuan salah satu definisi Humas yang diambil dari The British Institute of Public Relationberbunyi :

1. Public Relation activity is management of comunications between an organization and its publics. (Aktivitas public relation adalah mengelola komunikasi antara organisasi dan publiknya)

2. Public Relation practice is deliberate, planned and sustain effort to estabilish and maintain mutual undestanding between an organozation and its public (praktik public relations adalah memikirkan, merencanakan, dan mencurahkan daya untuk membangun dan menjaga saling pengertian antara organisasi dan publiknya). (Ruslan, 2011:15-16)".

\section{Peran Humas}

Pengertian peran adalah serangakaian perilaku yang diharapkan pada seseorang sesuai dengan posisi sosial yang diberikan baik secara formal maupun secara informal. Peran didasarkan pada preskripsi (ketentuan) dan harapan peran yang menerangkan apa yang individu-individu harus lakukan dalam suatu situasi tertentu agar dapat memenuhi harapan-harapan mereka sendiri atau harapan orang lain menyangkut peran-peran tersebut (Friedman, 1998: 286)

Menurut Sihab (2002: 854) peranan adalah bagian yang dimainkan seorang pemain, berusaha bermain baik disemua yang diembankan padanya, tindakan yang dilakukan oleh seseorang dalam suatu peristiwa. Peranan itu merupakan perilaku yang diharapkan dari seseorang yang mempunyai status atau kedudukan tertentu (Thoha, 2003: 10). Perkembangan profesionalisme Public Relationsyang berkaitan dengan pengembangan peranan Public Relation, baik secara praktis maupun profesional dalam suatu organisasi atau perusahaan menurut Dozier D.M (dalam Ruslan, 2007: 19) merupakan salah satu kunci memahami fungsi Public Relations dan komunikasi organisasi. Selain itu, hal tersebut juga merupakan kunci untuk pengembangan peranan PRO (pejabat humas) dan pencapaian profesionalisme dalam Public Relations.

Konsep peran atau peranan pada dasarnya merupakan konsep sosiologi, Soekanto mengemukakan pengertian peran sebagai berikut peran merupakan aspek dinamis dari status (kedudukan). Apabila organisasi melakukan hak dan kewajibanya sesuai dengan kedudukanya, maka ia atau mereka atau organisasi tersebut menjalankan peran. Peran lebih banyak menunjuk pada fungsi, penyesuaian diri dan sebagai suatu proses. Jadi tepatnya adalah seseorang menduduki suatu posisi atau tempat pada masyarakat serta menjalankan suatu peran. (Soekanto, 2010: 243)

Teori peran (role theory) adalah teori yang merupakan perpaduan berbagai teori, orientasi maupun disiplin ilmu,selain dari psikologi dan antropologi. Dalam teorinya Biddle \& Thomas (2008) yang dikutip oleh Sarlito Wirawan Sarwono dalam bukunya Teori-Teori psikologi Sosial membagi peristilahan dalam teori peran dalam 4 golongan, yaitu istilah-istilah yang menyangkut: 
1. Orang-orang yang mengambil bagian dalam interaksi sosial

2. Perilaku yang muncul dalam interaksi sosial tersebut

3. Kedudukan orang-orang dalam perilaku

4. Kaitan antara orang dan perilaku (Wirawan, 2008 :209)

Peran humas dalam suatu organisasi dapat dibagi menjadi empat kategori menurut Dozier dan Broom (dalam Ruslan, 2007: 20):

\section{Penasihat Ahli (Expert Prescriber)}

Seorang praktisi pakar humas yang dan berpengalaman dan memiliki kemampuan tinggi dapat membantu mencarikan solusi dalam penyelesaian masalah hubungan dengan publiknya (public relationship). Hubungan praktisi pakar humas dengan manajemen organisasi seperti hubungan dokter dengan pasiennya. Artinya pihak manajemen bertindak pasif untuk menerima atau yang disarankan atau usulan dari pakar humas (expert prescriber) tersebut dalam memecahkan dan mengatasi persoalan humas yang tengah dihadapi organisasi.

\section{Fasilitator Komunikasi (Communication Fasilitator)}

Dalam hal ini praktisi humas bertindak sebagai komunikator atau mediator untuk membantu pihak manajemen dalam hal untuk mendengar apa yang diinginkan dan diharapkan oleh publiknya. Dipihak lain dia juga dituntut mampu menjelaskan kembali keinginan, kebijakan dan harapan orgaisasi kepada publiknya. Sehingga dengan komunikasi timbal balik tersebut dapat terciptanya saling pengertian mempercayai, menghargai, mendukung dan toleransi yang baik dari kedua belah pihak.

\section{Fasilitator Proses Pemecahan Masalah (Problem Solving Process Fasilitator)}

Peranan praktisi humas dalam proses pemecahan persoalan humas ini merupakan bagian daritim manajemen. Hal ini dimaksudkan untuk membantu pimpinan organisasi baik sebagai penasihat (adviser) hingga mengambil tindakan keputusan dalam mengatasi persoalan atau krisis yang tengah dihadapi secara raisional dan professional. Biasanya dalam menghadapi suatu krisis yang terjadi, maka dibentuk suatu tim posko yang dikoordinir praktisi ahli humas dengan melibatkan sebagai departemen dan keahlian dalam suatu tim khusus untuk membantu organisasi, perusahaan dan produk yang tengah menghadapi atau mengatasi persoalan krisis tertentu.

\section{Teknisi Komunikasi (Communication Technication)}

Berbeda dengan peranan praktisi humas profesional sebelumnya yang terkait erat dengan fungsi dan peranan manajemen organisasi. Peranan teknisi komunikasi ini menjadikan praktisi humas sebagai journalist in organization. Sistem komunikasi dalam organisasi tergantung dari masing-masing bagian atau tingkat, yaitu secara teknis komunikasi, baik arus maupun media komunikasi yang dipergunakan dari 
tigkatan pimpinan dengan bawahan akan berbeda dari bawahan ke tingkat atasan. Hal ini yang sama juga berlaku pada arus dan media komunikasi antar level misalnya komunikasi antar karyawan satu departemen dengan lainnya (employe relations and communication media model).

\section{Citra}

Citra menurut Bill Canton (dalam Soleh Soemirat, 2007: 111) mengatakan bahwa citra adalah image: the impression, the feeling, the conceptions which the public has of a company: a cociossly created impression of an object person of organizations (citra adalah kesan, perasaan, gambaran dari publik terhadap perusahaan. kesan yang dengan disengaja diciptakan dari suatu objek, orang atau organisasi).

Citra diartikan sebagai kesan seseorang atau individu tentang sesuatu yang muncul sebagai hasil dari pengetahuan dan pengalamannya, citra sebagai gambaran tentang realitas dan tidak harus sesuai dengan realitas dan citra adalah dunia menurut persepsi (soemirat, 2007: 114)

Citra adalah tujuan utama sekaligus merupakan reputasi dan prestasi yang hendak dicapai bagi dunia PR. Pengertian citra sendiri sebenarnya abstrak dan tidak dapat diukur secara matematis. Tapi wujudnya bisa dirasakan dari hasil penilain baik atau buruk. Seperti penerimaan dan tanggapan baik positif maupun negatif yang khususnya datang dari publik (khalayak sasaran) dan masyarakat luas pada umumnya. (Ruslan, 2003:68).Lima jenis citra (image) yang dikemukakan oleh Frank Jefkins yaitu :

\section{Citra bayangan (mirror image)}

Citra ini melekat pada orang dalam atau anggota-anggota organisasi biasanya adalah pemimpinnya mengenai anggapan pihak luar tentang organisasinya. Citra yang dianut oleh orang dalam mengenai luar(eksternal) terhadap organisasinya. Hanya merupakan pandangan atau pengalaman seseorang terhadap organisasi atau perusahaan, citra ini timbul karena kurangnya informasi, pengetahuan dan pemahaman yang dimiliki oleh kalangan dalam organisasi mengenai pendapat pihak luar, jadi hanya berupa ilusi. Jadi citra bayangan cenderungan pada persepsi positif.

\section{Citra yang berlaku (current image)}

Suatu citra atau pandangan yang dianut oleh pihak-pihak luar mengenai suatu organisasi. Image atau pandangan dari eksternal perusahaan terhadap perusahaan, image yang terbentuk di public eksternal ini ditentukan dari informasi yang mereka dapat mengenai perusahaan, atau hanya sekedar ilusi. Image ini lebih cenderung pada image negative perusahaan (informasi atau pengalaman terbatas).

\section{Citra yang diharapkan (wish image)}

Suatu citra yang diinginkan oleh pihak manajemen. Suatu citra yang dibentuk sesuai dengan keingininan perusahaan atau organisasi. Citra yang diharapkan cenderung pada hal yang baik atau kesesuaian dengan publiknya. Sehingga dapat menarik respon masyarakat yang lebih luas. Citra harapan ini adalah citra yang selalu diingikan setiap perusahaan. Walaupun untuk pencapaiannya sangat sulit. 
Perusahaan juga harus mengetahui bagaimana proses public mendapatkan informasi kenyataan tentang perusahaan sehingga tidak terjadi kesalahpahaman.

\section{Citra perusahaan (corporate image)}

Citra dari suatu organisasi secara keseluruhan, jadi bukan sekedar citra atas produk dan pelayanannya.Citra perusahaan merupakan citra secara keseluruhan yang dipandang dari kinerja internal perusahaan yang meliputi sejarah, visi\& misi perusahaan, kualitas pelayanan, keberhasilan, hingga tanggung jawab sosial yang dijalankan perusahaan. Melalui hal tersebut public akan mengetahui gambaran pesan yang akan disampaikan dari perusahaan tersebut.

\section{Citra majemuk (multiple image).}

Banyaknya jumlah pegawai (individu), cabang, atau perwakilan dari sebuah perusahaan atau organisasi dapat memunculkan suatu citra yang belum tentu sama dengan organisasi. Image yang bermacam-macam dari public terhadap perusahaan akibat penyampaian, sikap, maupun tingkah laku yang berbeda dari setiap individu (karyawan) yang mewakili perusahaan tersebut dengan tujuan perusahaan. Image ini dapat dibentuk dengan melalui pakaian seragam, warna mobil, simbol, pelatihan staf, bentuk bangunan, papan nama, dan lain-lain.

\section{METODE PENELITIAN}

Pada penelitian ini digunakan desain penelitian kualitatif. Penelitian kualitatif ini mengarah pada pendekatan deskriptif, yaitu berupa memberikan gambaran situasi dan menganalisi data-data berdasarkan kegiatan pelaksanaan survey dilapangan. Agar memperoleh kesimpulan yang objektif maka peneliti mencoba mendalami dan berusaha untuk menuturkan pemecahan masalah yang ada dengan mengacu berdasarkan data-data serta menganalisa dan menginterpretasikan masalah atau mengumpulkan kombinasi dari berbagai permasalahan yang ada.

Subjek dalam penelitian ini adalah Humas PT. Indah Kiat Pulp \&Paper Perawang yang dianggap perlu sebagai informan kunci (key informan), tiga orang bagian humas, dua orang karyawan produksidan tiga orang masyarakat sekitar. Untuk pengambilan informasi yang penulis lakukan dalam penelitian ini adalah menggunakan informan yang ditetapkan dengan sebuah purposive sampling, maksudnya ialah pengambilan sampel dilakukan dengan cara mengambil subjek bukan berdasarakan strata random atau daerah tetapi berdasarkan atas adanya tujuan tertentu (Arikunto, 2000:127).

Sedangkan yang menjadi objek dalam penelitian ini adalah peran humas PT.IKPP Perawang dalam upaya menumbuhkan citra positif masyarakat Desa Tualang Kabupaten Siak. 


\section{PEMBAHASAN}

\section{Peran Humas PT. Indah Kiat Pulp \& Paper dalam Upaya Menumbuhkan Citra Positif Masyarakat Desa Tualang Kabupaten Siak.}

PT. Indah Kiat Pulp \& Paper Perawang merupakan perusahaan swasta yang bergerak dibidang pembuatan kertas dan Pulp. Untuk mempertahankan bahan baku perusahaan, PT. Indah Kiat Pulp \& Paper bekerja sama dengan anak perusahaannya yaitu PT. Arara Abadi sebagai perusahaan penghasil kayu bahan dasar kertas. Selain menjalin hubungan dengan pihak yang bisa menunjang kemajuan perusahaan. untuk mempertahankan dan memperoleh kesuksesan, perusahaan ini harus mampu mempertahankan nama baik perusahaan di mata publik internal maupun eksternal. Dengan demikian, kerja sama yang baik antara perusahaan dengan masyarakat eksternal, pihak pemasok, pemegang saham, dan pihak yang berkepentingan di dalam perusahaan yang baik akan menunjang keberhasilan dan kesuksesan suatu perusahaan.

Pekerjaaan humas dalam suatu perusahaan bukan saja mengumpulkan artikel, namun dalam pekerjaannya juga harus melakukan hal-hal penting seperti survey tempat, dan melakukan evaluasi tentang apa yang akan dilakukan. Jika memang terdapat suatu kesalah pahaman masyarakat tentang perusahaan tempat dimana humas itu bekerja, maka ia harus bisa mengakali dengan cara apapun untuk mengembalikan citra perusahaan tersebut. Pekerjaan humas sangat erat kaitannya dengan pers apalagi humas perusahaan, humas perusahaan harus bisa mengakrabkan diri dengan media karna media mempunyai peran sangat penting dalam mempublikasikan suatu hal atau berita yang berkaitan dengan perusahaan.

Keberadaan humas bagi suatu perusahaan merupakan suatu keharusan sama halnya degan Humas PT. Indah Kiat Pulp \& Paper yang memiliki peran yang sangat amat penting, terutama dalam hal yang menyangkut pada citra perusahaan baik dalam hal pembentukan citra, membangun, memperbaiki maupun menumbuhkan citra suatu perusahaan. Humas bertugas agar dapat menampung dan menjawab segala keluhan, tuntutan dan kebutuhan yang diajukan oleh masyarakat dilingkungan perusahaan, mengingat perusahaan ini berdiri dan tumbuh kembang dilingkungan sekitarnya yang secara tidak langsung mempengaruhi jalannya perusahaan tersebut. Hasil penelitian ini akan dijelaskan berdasarkan hasil wawancara penulis sebagai berikut:

"Humas PT. Indah Kiat Pulp \& Paper sampai saat ini berusaha bekerja sebaik mungkin dengan cara mengamati dan memperhatikan perilaku publik atau masyarakat, serta bagaimana opini atau apa saja yang sedang berkembang masyarakat. Hal ini dilakukan tidak lain agar setiap kegiatan perusahaan terus mendapatkan dukungan dari publik". (Wawancara dengan Kepala Seksi Humas PT. Indah Kiat Pulp \& Paper, 16 Desember 2015)

Dari penjelasan Humas PT. Indah Kiat Pulp \& Paper tersebut, dapat dilihat bahwa pihak humas PT. Indah Kiat Pulp \& Paper terus berusaha dan bekerja sebaik mungkin dalam mengamati perilaku publik seperti sikap atau opini apa saja yang 
sedang berkembang di masyarakat guna mendapatkan dukungan publik agar dapat menumbuhkan citra positif dari publik itu sendiri.

Hal ini senada dengan pendapat Ruslan yaitu humas adalah fungsi manajemen yang mengevaluasi opini, sikap, dan perilaku publik, mengidentifikasi kebijakankebijakan dan prosedur-prosedur suatu individu atau sebuah organisasi dengan kepentingan publik, dan merencanakan serta melaksanakan program aksi untuk memperoleh pengertian dan dukungan publik (Ruslan, 2007: 25).

Pekerjaan seorang humas tidak pernah jauh-jauh dari kegiatan komunikasi. Secara umum komunikasi merupakan proses penyampaian atau pertukaran pesan, gagasan, harapan, yang dilakukan oleh komunikator pada komunikan dengan tujuan terciptanya suatu kondisi yang harmonis dan terciptanya persamaan makna. Proses komunikasi ini bisa dilakuakan baik dengan cara bertemu langsung atau tatap muka (face to face) dan dapat juga dilakukan dengan cara memanfaatkan media. Hal itu juga berlaku pada humas PT. Indah Kiat Pulp \& Paper yang dapat dilihat dari bagaimana keseharian dalam kinerja seorang humas yang di tuntut harus cakap melakukan kegiatan komunikasi baik berkomunikasi dalam lingkungan perusahaan meliputi komunikasi dengan atasan, rekan kerja serta dengan karyawan perusahaan maupun komunikasi dengan masyarakat sekitar area perusahaan. Komunikasi juga dapat diartikan sebagai proses penyampaian suatu pikiran atau suatu perasaan yang dirasakan oleh suatu individu yang kemudian disampaikan kepada orang yang ada disekitar dengan tujuan dapat berinteraksi dan dapat mengakrabkan diri satu sama lainnya.

"Seorang humas harus mampu berkomunikasi dengan baik serta mengakrabkan diri dengan lingkungannya, seperti dengan atasan, rekan kerja dan lain-lain yang ada dalam perusahaan. hal ini dilakukan agar tidak terciptanya semacam jarak pemisah dalam suatu organisasi dan teciptanya suasana yang nyaman dalam bekerja. (Hasil wawancara dengan bapak Ruslinur Jarot selaku humas bagian sosial, 16 Desember 2015).

Inti tugas humas adalah sinkronisasi antara informasi dari perusahaan dengan reaksi dan tanggapan dari publik sehingga mencapai saling pengertian dan hubungan harmonis antara kedua belah pihak. Adapun ruang lingkup humas dalam sebuah organisasi atau instansi menurut Suhandang (2009:73) antara lain :

\section{Membina hubungan kedalam (Publik Internal)}

Kegiatan ini diperlukan untuk memupuk suasana yang menyenangkan diantara para karyawannya, komunikasi antara bawahan dan pimpinan atau atasan terjalin dengan akrab dan tidak kaku, serta meyakini rasa tanggung jawab akan kewajibannya terhadap perusahaan.

\section{Membina hubungan keluar (Publik Eksternal)}

Komunikasi dengan semua publik eksternal hendaknya dilakukan secara informatif dan persuasif. Informasi hendaknya diberikan secara jujur, teliti, dan sempurna berdasarkan fakta yang sebenarnya. Karenanya sifat yang ramah 
merupakan salah satu syarat yang bisa menentukan berhasil tidaknya usaha eksternal suatu perusahaan”.

Humas PT. Indah Kiat Pulp \& Paper memiliki upaya yang terencana dan berkesinambungan, yang dapat diartikan bahwa seorang humas dalam kinerjanya memiliki beberapa program kegiatan yang telah diorganisasikan sebagai suatu rangkaian kampanye atau program terpadu dan semuanya berlangsung dan berjalan secara berkesinambungan dan teratur. Jadi setiap kegiatan yang dilakukan oleh humas PT. Indah Kiat Pulp \& Paper bukanlah berupa kegiatan yang sifatnya sembarangan atau dadakan. Sementara yang dimaksud dengan tujuan utamanya untuk menciptakan dan memelihara saling pengertian ialah untuk memastikan bahwa perusahaan tersebut dimengerti oleh pihak-pihak yang ikut berkepentingan baik lingkungan internal maupun lingkungan eksternal.

Humas PT. Indah Kiat Pulp \& Paper berperan dalam mengkomunikasikan setiap program-program dengan cara mensosialisasikan dan mempublikasikan programprogram humas yang ada bisa melalui media. Perusahaan menyediakan informasi melalui situs resmi yang dimiliki PT. Indah Kiat Pulp \& Paper agar masyarakat luas dapat mengetahui mengenai apa-apa saja yang menjadi visi, misi, dan serta gambaran umum mengenai tugas dan program-program apa saja yang dijalankan oleh Humas PT. Indah Kiat Pulp \& Paper.

Kemudian Humas PT. Indah Kiat Pulp \& Paper mengembangkan program yang ada dan juga bertanggung jawab atas penerapannya, ini dikarenakan evaluasi kerja dan evaluasi atas program yang telah diterapkan ke masyarakat harus dilakukan peninjauan guna melihat kembali apakah program yang telah direncanakan sebelumnya telah benar-benar diterapkan atau dijalankan, apakah semua ketentuan sudah ditaati dan dilaksanakan oleh masyarakat.

"Humas memiliki peran yang sangat vital baik dalam menjalankan suatu program dan juga mengawasi dalam pelaksanaannya. seorang humas juga dituntut harus memiliki daya berfikir atau cara berfikir yang cepat dalam menanggapi suatu permasalahan yang ada, dan secepat mungkin untuk mencarikan solusi yang pas terhadap persoalan yang sedang dihadapi oleh perusahaan". (Wawancara dengan Kepala Seksi Humas PT. Indah Kiat Pulp \& Paper, 16 Desember 2015)

Berdasarkan pemaparan mengenai peran humas yang ada diatas maka dapat dilihat bahwa Humas PT. Indah Kiat Pulp \& Paper berperan sebagai fasilitator komunikasi dan fasilitator proses pemecahan masalah. Humas PT. Indah Kiat Pulp \& Paper berperan dalam mengkomunikasikan setiap program-program dengan cara mensosialisasikan dan mempublikasikan program-program humas yang ada serta turut aktif berperan dalam menemukan solusi untuk pemecahan suatu permasalahan yang sedang dihadapi perusahaan. Dalam peran humas menurut Dozier dan Broom yaitu Penasihat Ahli (Expert Presciber): Humas PT. Indah Kiat Pulp \& Paper mengembangkan program yang ada dan juga bertanggung jawab atas penerapannya, ini dikarenakan evaluasi kerja dan evaluasi atas program yang telah diterapkan ke masyarakat harus dilakukan peninjauan 
guna melihat kembali apakah program yang telah direncanakan sebelumnya telah benar-benar diterapkan atau dijalankan, apakah semua ketentuan sudah ditaati dan dilaksanakan oleh masyarakat. Kemudian Humas PT. Indah kiat Pulp \& Paper juga telah menjalankan Fasilitator Komunikasi (Communication Facilitator): hal ini dapat dilihat dengan menyediakan informasi melalui situs resmi yang dimiliki PT. Indah Kiat Pulp \& Paper agar masyarakat luas dapat mengetahui mengenai apa-apa saja yang menjadi visi, misi, dan serta gambaran umum mengenai tugas dan program-program apa saja yang dijalankan oleh Humas PT. Indah Kiat Pulp \& Paper.

Dalam peran Fasilitator Proses Pemecahan Masalah (Problem Solving Process Fasilitator) dan Teknisi Komunikasi (Communication Technician) Humas PT. Indah Kiat Pulp \& Paper sudah menjalankan perannya dengan baik. Namun humas PT. Indah Kiat Pulp \& Paper tidak ikut serta dalam membuat dan merancang suatu kebijakan, humas PT. Indah Kiat Pulp \& Paper hanya bertugas dalam menjalankan perannya sebagai pihak yang mensosialisasikan kebijakan yang ada kepada masyarakat.

Penulis melihat peran Humas PT. Indah Kiat Pulp \& Paper dalam upaya menumbuhkan citra positif masyarakat Desa Tualang Kabupaten Siak sesuai dengan teori Dozier dan Broom (dalam Ruslan, 2007:19) yaitu:

Peran humas dalam suatu organisasi dapat dibagi menjadi empat kategori yaitu:

\section{1) Penasihat Ahli (Expert Prescriber)}

Seorang praktisi pakar humas yang berpengalaman dan memiliki kemampuan tinggi dapat membantu mencarikan solusi dalam penyelesaian masalah hubungan dengan publiknya (public relationship). Hubungan praktisi pakar humas dengan manajemen organisasi seperti hubungan dokter dengan pasiennya. Artinya pihak manajemen bertindak pasif untuk menerima atau yang disarankan atau usulan dari pakar humas (expert prescriber) tersebut dalam memecahkan dan mengatasi persoalan humas yang tengah dihadapi organisasi.

\section{2) Fasilitator Komunikasi (Communication Fasilitator)}

Dalam hal ini praktisi humas bertindak sebagai komunikator atau mediator untuk membantu pihak manajemen dalam hal untuk mendengar apa yang diinginkan dan diharapkan oleh publiknya. Dipihak lain dia juga dituntut mampu menjelaskan kembali keinginan, kebijakan dan harapan orgaisasi kepada publiknya. Sehingga dengan komunikasi timbal balik tersebut dapat terciptanya saling pengertian mempercayai, menghargai, mendukung dan toleransi yang baik dari kedua belah pihak.

\section{3) Fasilitator Proses Pemecahan Masalah (Problem Solving Process Fasilitator)}

Peranan praktisi humas dalam proses pemecahan persoalan humas ini merupakan bagian dari tim manajemen. Hal ini dimaksudkan untuk membantu 
pimpinan organisasi baik sebagai penasihat (adviser) hingga mengambil tindakan keputusan dalam mengatasi persoalan atau krisis yang tengah dihadapi secara raisional dan professional. Biasanya dalam menghadapi suatu krisis yang terjadi, maka dibentuk suatu tim posko yang dikoordinir praktisi ahli humas dengan melibatkan sebagai departemen dan keahlian dalam suatu tim khusus untuk membantu organisasi, perusahaan dan produk yang tengah menghadapi atau mengatasi persoalan krisis tertentu.

\section{4) Teknisi Komunikasi (Communication Technication)}

Menyediakan layanan teknis komunikasi atau dikenal dengan metode of communication in organization dan sistem komunnikasi dalam organisasi tergantung dari masing-masing bagian atau tingkatan. Baik itu arus maupun media yang digunakan. Humas dalam menjalankan peran ini biasanya tidak ikut serta saat manajemen mendefinisikan masalah dan mencapai dan mencari jalan keluar. Humas harus terlibat untuk memproduksi komunikasi dan menerapkan program, yang terkadang tanpa bekal pengetahuan yang utuh tentang motivasi asal atau hasil yang diinginkan. Meskipun humas tidak diikut sertakan dalam diskusi tentang kebijakan baru atau kepuasan manajemen, humas adalah pihak yang dilimpahkan tugas memberikan penjelasan pada karyawan dan pers.

Humas bertujuan untuk menegakkan dan menumbuhkan serta mengembangkan citra yang menguntungkan bagi organisasi atau perusahaan, produk dan jasa terhadap para stakeholdernya sebagai sasaran yang terkait yaitu publik internal dan publik eksternal. Untuk mencapai tujuan tersebut, strategi kegiatan humas semestinya diarahkan pada upaya menggarap persepsi para stokeholder. Konsekuensinya jika strategi penggarapan itu berhasil, maka akan diperoleh sikap tindak dan persepsi yang sangat menguntungkan dara pihak stokeholder sebagai sasarannya. Maka pada akhirnya akan tercipta suatu opini dan citra yang sangat menguntungkan bagi perusahaan.

Proses pembentukan citra pada akhirnya akan menghasilkan sikap, pendapat, tanggapan atau perilaku yang baik pula dan hal inilah yang perlu ditingkatkan oleh perusahaan dan mempertahankannya. Fungsi dan tugas seorang humas berbeda dengan peran yang dijalankan oleh marketing dan promosi. Marketing hanya sekedar menjual barang dan jasa kepada konsumen, sementara humas memberi kepercayaan kepada masyarakat berupa persepsi yang baik terhadap instansinya. Jadi humas berfungsi untuk mendengarkan dan mengetahui setiap respon dari masyarakat dan keinginan masyarakat, serta isu-isu yang berkembang ditengah masyarakat. Baik berupa isu positif maupun isu negative. Dari respon masyarakat tersebut seorang humas bisa menarik kesimpulan dan mengetahui apakah tujuan instansi maupun lembaga sudah diterima masyarakat atau belum. Dan dari respon masyarakat juga humas dapat melakukan evaluasi dan menentukan langkah-langkah serta strategi guna mencapai tujuan atau target yang hendak dicapai.

"Tugas dari seorang humas adalah sebagai perpanjangan tangan atau sebagai suatu bagian dari perusahaan yang paling dekat dengan masyarakat sekitar 
dari perusahaan, pelaksanaan rencana kerja, penyusun program, pengawasan, melakukan evaluasi dan publikasi. Serta seorang humas juga harus mau turun ke lapangan guna memperoleh data yang nyata mengenai bagaimana citra yang berkembang dikalangan masyarakat." (hasil wawancara dengan bapak Ruslinur Jarot selaku humas bagian sosial, 16 Desember 2015)

"humas merupakan profesi yang memegang kendali penuh suatu perusahaan agar perusahaan tersebut dapat berjalan dengan baik, humas diharapkan melakukan pekerjaanya sebaik mungkin dengan tujuan dapat membangun citra perusahaan sehingga apapun yang menjadi tujuan dari perusahaan akan tercapai dengan mudah." (hasil wawancara dengan ibu Irmai Sastri Arsih selaku sekretaris humas, 16 Desember 2015)

Berdasarkan hasil wawancara diatas maka penulis membandingkan dengan pendapat yang dikemukakan oleh seorang ahli yaitu menurut H. Fayol (dalam Nova, 2011: 56) beberapa sasaran kegiatan Public Relation adalah sebagai berikut:

1. Membangun identitas dan citra perusahaan (building corporate identity and image):

a. Menciptakan identitas dan citra perusahaan yang positif.

b. Mendukung kegiatan komunikasi timbal balik dua arah dengan berbagai pihak.

2. Menghadapi krisis (facing of crisis)

Menangani keluhan (complaint) dan menghadapi krisis yang terjadi dengan membentuk manajemen krisis.

3. Mempromosikan aspek kemasyarakatan (promotion public causes):

a. Mempromosikan yang menyangkut kepentingan publik.

b. Mendukung kegiatan kampanye sosial, seperti anti merokok dan menghindari obat-obat terlarang dan sebagainya.

Dari pemaparan diatas maka penulis menyimpulkan bahwa terdapat beberapa kesamaan dari sasaran kegiatan Humas PT. Indah Kiat Pulp \& Paper dengan apa yang dikemukakan oleh H. Fayol (dalam Nova, 2011: 56) yaitu seorang humas menciptkan identitas dan citra perusahaan yang positif, mendukung kegiatan komunikasi dua arah serta mempromosikan aspek kemasyarakatan.

Dalam penelitian ini penulis juga mengambil data wawancara dari beberapa warga sekitar lingkungan perusahaan, wawancara ini dilakukan guna untuk menanyakan beberapa hal yang dianggap perlu bagi penulis untuk melengkapi dari penelitian yang sedang dilakukan. Selain dirasa beraktifitas dekat dengan lingkungan perusahaan, masyarakat dianggap penting untuk dimintai keterangan 
karena merekalah yang tahu betul bagaimana kondisi perusahaan atau mengenai citra perusahaan saat ini.

"Menurut saya citra perusahaan mulai menurun dapat dilihat dengan mulai berkurangnya bantuan dari perusahaan, seperti bantuan peminjaman dana berupa modal dan pemberian bibit pada sektor pertanian dan peternakan bagi masyarakat usaha kecil yang sangat berpengaruh apalagi yang tidak memiliki pekerjaan tetap."

(Febri randika, 30 tahun. 19 Maret 2016)

"Saya merasa begitu sulitnya untuk mendapatkan lowongan pekerjaan di perusahaan ini, padahal saya telah mengikuti segala prosedur yang ditentukan dari pihak perusahaan dan sudah berulang-ulang juga saya mengantar lamaran namun belum ada jawaban yang pasti sampai sekarang. Pihak perusahaan hanya mengatakan akan menghubungi dan menunggu kabar dari perusahaan." (Arpen Saputra, 28 tahun. 19 Maret 2016)

"Citra perusahaan dirasa biasa saja, namun perusahaan sekarang ini kurang aktif dalam mengadakan event-event tertentu seperti acara minggu sehat yang dulu selalu dilaksanakan rutin dalam tiap dua minggu sekali diadakan di area lapangan sepak bola perusahaan. Acara ini dinilai berdampak baik bagi citra dari perusahaan itu sendiri karna dengan semakin banyak warga yang hadir menunjukkan bahwa masyarakat berpartisipasi pada setiap kegiatan yang diadakan oleh perusahaan.” (Mukhlis Wahyu, 45 tahun. 19 Maret 2016)

Berdasarkan hasil wawancara dengan beberapa warga masyarakat diatas dapat disimpulkan bahwa citra dari PT. Indah Kiat Pulp \& Paper Perawang dinilai atau dirasakan mulai menurun, hal itu sejalan dengan adanya keluhan-keluhan mengenai pelaksanaan program pengembangan ekonomi, sulitnya dalam mendapatkan lowongan pekerjaan dan berkurangnya program dalam pengadaaan event-event tertentu yang diungkapkan dari masyarakat yang ada disekitar daerah operasional perusahaan.

Selama perusahaan berdiri tentunya perusahaan tidak hanya berjalan dengan mulus sesuai yang diharapkan dan yang menjadi cita-cita dari awal terbentuknya perusahaan tersebut. Dalam keseharian tentu akan ada tiba waktunya menemui hambatan atau batu terjal yang menuntut keterampilan dari seorang humas dalam menyikapinya, seperti dalam bentuk adanya opini negatif yang berkembang ditengah-tengah masyarakat dan berdampak negatif pula pada citra terhadap suatu perusahaan.

Hal yang paling buruk bisa menimpa suatu perusahaan ketika tidak memiliki solusi yang pas saat mengalami konflik dengan masyarakat sekitar dikarenakan dengan adanya suatu isu negatif yang berkembang yang tidak bisa ditanggulangi atau diselesaikan. Seorang humas profesional tentunya akan tetap berfikir jernih ketika harus menghadapi isu negatif yang menimpa perusahaan dimana tempat ia bekerja, hal ini ditanggapi sebagai tantangan bagi dirinya guna mengembalikan 
lagi citra perusahaan sebagaimana mestinya dan bisa dianggap sebagai prestasi bila isu atau opini negatif yang beredar telah tidak muncul kembali kepermukaan.

Dan ketika masa itu datang maka keberlanjutan perusahaan akan bergantung pada bagaimana sikap dan tangan dingin atau cara seorang humas dalam menyikapi dan mensiasati tentang opini negatif yang ada. Yang menjadi pertanyaan adalah bagaimanakah peran seorang humas dalam menyikapi opini negatif yang berkembang di masyarakat yang berdampak negatif pula bagi citra perusahaan?

"Seorang humas harus memiliki mental yang kuat dalam menyikapi berbagai persoalan yang ada dan menghadapinya dengan tenang. Dalam menyikapi isu negatif yang berkembang, maka seorang humas harus menjelaskan mengenai kondisi sebenarnya yang sedang terjadi yang mungkin tidak diketahui seluruhnya oleh masyarakat. Hal itu bisa dilakukan dengan cara membina hubungan melalui dialog dan diskusi dengan mengundang masyarakat. Karna masyarakat tidak akan mengubah persepsi mereka selama belum mendapatkan penjelasan yang datang langsung dari pihak perusahaan." (Hasil wawancara dengan Kepala Seksi Humas PT. Indah Kiat Pulp \& Paper, 16 Desember 2015)

"Dalam menyikapi citra negatif yang berkembang maka humas harus cepat tanggap dalam manyikapi permasalahan yang ada dan tidak membiarkan suatu masalah itu berlarut- larut sehingga menimbulkan kerugian yang cukup besar bagi perusahaan. dalam hal ini kami melakukan komunikasi dengan masyarakat guna melakukan diskusi agar menemukan jalan terbaik bagi kedua belah pihak yang selama ini selalu berhasil kami laksanakan. Hal ini kami lakukan sebagai bukti aktif dalam membina hubungan silaturahmi dalam bentuk cara meningkatkan hubungan peran humas sebagai wadah hubungan masyarakat." (Wawancara dengan Ibu Irmai Sastri Arsih selaku sekretaris humas, 16 Desember 2015).

Berdasarkan pemaparan diatas maka dapat diambil kesimpulan bahwa peran seorang humas dalam suatu oarganisasi atau perusahaan adalah sebagai media untuk membangun dan memelihara jalur komunikasi yang sebelumnya mengalami hambatan atau kendala, oleh karena itu seorang humas ditugaskan untuk memperbaiki setiap permasalahan-permasalahan dengan memberikan solusi yang pas agar masalah dapat diselesaikan. Humas merupakan mediator yang berada diantara pimpinan perusahaan dengan publiknya dalam rangka mencapai tujuantujuan spesifik yang berlandaskan saling pengertian.

Dalam melaksanakan tugasnya untuk menumbuhkan citra positif, humas PT. Indah Kiat Pulp \& Paper senantiasa memberikan informasi baik mengenai profil perusahaan maupun program-program yang akan dijalankan melalui sarana media cetak maupun media elektronik. Seperti bisa melalui dari buletin, majalah dan media sosial. Hal ini dilakukan guna mempermudah kinerja humas dalam mempublikasikan informasi-informasi yang dianggap penting oleh perusahaan guna diketahui oleh masyarakat luas. 
"Media merupakan sarana yang sangat membantu dalam memberikan informasi-informasi penting kepada masyarakat luas, karena melalui media masyarakat lebih dapat memahami dan mengerti tentang informasi atau program-program apa yang disampaikan perusahaan karna dapat dibaca berulang-ulang."

(Wawancara dengan Kepala Seksi Humas Indah Kiat Pulp \& Paper, 5 Januari 2016)

"Media adalah bagian yang sangat penting guna mencegah terjadinya kesalah pahaman terhadap suatu hal atau informasi yang ingin disampaikan dan sangat membantu dalam berkomunikasi serta publikasi. Media sangat mempermudah kita karna melalui media suatu informasi bisa kita sebarkan kapanpun dan dimanapun."

(Wawancara dengan Ibu Irmai Sastri Arsih selaku sekretaris humas, 5 Januari 2016)

Berdasarkan hasil wawancara diatas maka penulis dapat menarik kesimpulan bahwa Humas PT. Indah Kiat Pulp \& Paper juga memanfaatkan media yang ada sebagai salah satu sarana untuk mempublikasikan informasi-informasi ataupun program-program yang ada. Media digunakan agar mempermudah tercapainya tujuan yang ingin disampaikan pada masyarakat luas, serta untuk meminimalisir terjadinya kesalahan makna atau persepsi, karena dengan melalui media masyarakat bisa membaca informasi yang ada secara berulang-ulang.

\section{KESIMPULAN}

Peran humas PT. Indah Kiat Pulp \& Paper dalam menumbuhkan citra positif masyarakat Desa Tualang Kabupaten Siak antara lain :

a. Humas PT. Indah Kiat Pulp \& Paper berperan dalam mengkomunikasikan setiap program-program dengan cara mensosialisasikan dan mempublikasikan program-program humas yang ada serta turut aktif berperan dalam menemukan solusi untuk pemecahan suatu permasalahan yang sedang dihadapi perusahaan.

b. Humas PT. Indah Kiat Pulp \& Paper mengembangkan program yang ada dan juga bertanggung jawab atas penerapannya, ini dikarenakan evaluasi kerja dan evaluasi atas program yang telah diterapkan ke masyarakat harus dilakukan peninjauan guna melihat kembali apakah program yang telah direncanakan sebelumnya telah benar-benar diterapkan atau dijalankan, apakah semua ketentuan sudah ditaati dan dilaksanakan oleh masyarakat.

c. Tugas dari humas PT. Indah Kiat Pulp \& Paper adalah sebagai perpanjangan tangan dari perusahaan, pelaksanaan rencana kerja,penyusun program, pembinaan, pengawasan, koordinasi, sinkronisasi, monitoring dan evaluasi dibidang pengumpulan informasi, penerangan danpublikasi. Serta humas PT. Indah Kiat Pulp \& Paper juga mau turunke lapangan guna memperoleh data yang nyata mengenai bagaimana citra yang berkembang dikalangan masyarakat. 
d. Dalam upaya menumbuhkan citra positif masyarakat Desa Tualang, PT.Indah Kiat Pulp \&Paper membentuk humas agar dapat menampung dan menjawab segala keluhan, tuntutan dan kebutuhan yang diajukan oleh masyarakat dilingkungan perusahaan, mengingat perusahaan ini berdiri dan tumbuh kembang dilingkungan sekitarnya yang secara tidak langsung mempengaruhi jalannya perusahaan tersebut. Melalui program atau kegiatan-kegiatan kerja humas, humas PT.Indah Kiat Pulp \&Paper mensosialisasikan programprogram kerja humas kepada masyarakat agar menimbulkan citra positif terhadap perusahaan dari masyarakat wilayah operasional.

Dalam melaksanakan tugasnya untuk menumbuhkan citra positif, humas PT. Indah Kiat Pulp \& Paper senantiasa memberikan informasi baik mengenai profil perusahaan maupun program-program yang akan dijalankan melalui sarana media cetak maupun media elektronik. Seperti bisa melalui dari buletin, majalah dan media sosial.Hal ini dilakukan guna mempermudah kinerja humas dalam mempublikasikan informasi-informasi yang dianggap penting oleh perusahaan guna diketahui oleh masyarakat luas.

\section{DAFTAR PUSTAKA}

Arikunto, Suharsimi.2000. Prosedur Penelitian Suatu Pendekatan Praktik. Rineka Cipta: Jakarta

Abdurrachman, Oemi. 2001. Dasar-dasar Public Relation. Citra Aditya Bakti: Bandung

Bungin, Burhan. 2003. Analisa Data Penelitian Kualitatif. Raja Grafindo Persada: Jakarta

Cangara, Hafid. 2005. Pengantar Ilmu Komunikasi. Raja Grafindo Persada: Jakarta

Cornelissem. 2008. Corporate Image Management A Marketing Discipline For The $21^{\text {st }}$ Century, Reed Educational And Professional Publishing Ltd. Worburn

Keith, Butterick.2012. Pengantar Public Relation: Teori Dan Praktik.. Pt Raja Grafindo Persada: Jakarta

Effendy, Onong Uchjana. 1992. Komunikasi dan Modernisasi. Alumni : Bandung 2004. Dinamika Komunikasi. Remaja Rosda Karya: Bandung 2005. Ilmu Komunikasi Teori Dan Praktek. Remaja Rosda Karya: Bandung

Iriantara, Yosal. 2004. Community Relations Konsep dan Aplikasinya, Simbiosa Rekatama Media: Bandung

Kennedy, J.E. Soemanagara. 2006. Marketing Communication: Taktik dan Strategi. PT. Buana Ilmu Populer: Jakarta

Kriyantono, Rachmat. 2007. Teknis Praktis Riset Komunikasi. Kencana Prenada Media Group: Jakarta 
Mansyur, Cholic, M. 2000. Sosiologi Masyarakat Kota dan Desa. Usaha Nasional: Surabaya

Moleong, Lexy J. 2004. Metodologi Penelitian Kualitatif. Remaja Rosda Karya: Bandung

2005. Metodologi Penelitian Kualitatif.Remaja Rosda Karya: Bandung

Moore, Frazier. 2005. Humas Membangun Citra Dengan Komunikasi. Remaja Rosda Karya: Bandung

Morrison. 2008. Manajemen Public Relation: Strategi Menjadi Humas. Remaja Rosda Karya: Bandung

Muhammad, Arni. 2011. Komunikasi Organisasi. Bumi Aksara: Jakarta

Nova, Firsan. 2011. Crisis Public Relation. Raja Grafindo persada: Jakarta

Putra, Nugrah, I Gusti. 2011. Manajemen Hubungan Masyarakat. Universitas Atmajaya Yogjakarta:Yogyakarta

Ruslan, Rosadi. 2003. Metode Penelitian Public Relations dan komunikasi. Raja Grafindo Persada: Jakarta

2005. Manajemen Public Relation dan Media Komunikasi. Rajawali Pers: Jakarta

2007. Manajemen Public Relations \& Media Komunikasi: Konsepsi dan Aplikasi. PT Raja Grafindo Persada: Jakarta

2011. Etika Kehumasan (Konsepsi dan Aplikasi). PT Raja Grafindo Persada: Jakarta

Sihab, Alwis. 2003. Kamus Besar Bahasa Indonesia. Balai Pustaka: Jakarta

Suhandang, Kustadi. 2004. Public Relation Perusahaan. Nusantara: Bandung

Soemirat, Soleh dan Ardianto, Elvinaro. 2004. Dasar-dasar Public Relations. Remaja Rosda Karya: Bandung

Thoha, Miftah. 2003. Manajemen Dalam Kepemimpinan. Raja Grafindo Persada: Jakarta

Tinambunan, W.E. 2002. Teori-Teori Komunikasi. Swakarya: Jakarta

Umar, Husain. 2002. Metode Riset Komunikasi Organisasi. Gramedia Pustaka Utama: Jakarta

Wasesa, Silih, Agung. 2005. Strategi Public Relations.Gramedia Pustaka Utama: Jakarta

Widjaja, W. 2010. Komunikasi dan Hubungan Masyarakat. Bumi Aksara: Jakarta

\section{Sumber Lain}

Dresti Kusuma Sari. 2010. Peran Humas PT. Jamsostek (Persero) Kanwil V Jawa Tengah \& DIY Dalam Membangun Citra Perusahaan Melalui Program CSR Kemitraan dan Bina Lingkungan di Semarang (Jurnal).Jurusan Ilmu Komunikasi Fakultas Ilmu Sosial dan Ilmu Politik Universitas Diponegoro Semarang 